\title{
Evaluation of stress response in atropine - midazolam premedicated dogs under epidural dexmedetomidine, with or without local anaesthetics
}

\author{
Mudasir Ahmad Shah*, Prakash Kinjavdekar, Amarpal, Deepti Sharma, \\ Rohit Kumar, Nitish Kallianpur, Shivaraju Shivaramu, \\ and Praveen Kamaraj
}

Division of Surgery, Indian Veterinary Research Institute, Izatnagar, India

\begin{abstract}
SHAH, M. A., P. KINJAVDEKAR, AMARPAL, D. SHARMA, R. KUMAR, N. KALLIANPUR, S. SHIVARAMU, P. KAMARAJ: Evaluation of stress response in atropine - midazolam premedicated dogs under epidural dexmedetomidine, with or without local anaesthetics. Vet. arhiv 88, 823-834, 2018.
\end{abstract}

\section{ABSTRACT}

The aim of our study was to evaluate stress response in atropine-midazolam premedicated dogs under epidural dexmedetomidine alone or with local anaesthetics. A total of 24 healthy, client-owned mixed breed adult dogs, with an average weight of $18.1 \pm 2.4 \mathrm{~kg}$ were allotted randomly $(\mathrm{n}=6)$ to four groups, viz: A, B, C and D. All the animals were premedicated intramuscularly with atropine $(0.04 \mathrm{mg} / \mathrm{kg})$ and after 5 minutes by intravenous midazolam $(0.7 \mathrm{mg} / \mathrm{kg})$. After 10 minutes of premedication, in group A dexmedetomidine $(7 \mu \mathrm{g} / \mathrm{kg})$ and in groups B, C and D, in addition to dexmedetomidine $(7 \mu \mathrm{g} / \mathrm{kg})$, lidocaine $(4.4 \mathrm{mg} / \mathrm{kg})$, bupivacaine $(2 \mathrm{mg} /$ $\mathrm{kg})$ and ropivacaine $(2 \mathrm{mg} / \mathrm{kg})$ were administered, respectively, at the lumbosacral epidural space. Anaesthesia was maintained with 1 per cent propofol as and when needed. Stress response during the surgical procedure was evaluated and assessed by measuring plasma levels of insulin, glucose, cortisol and blood neutrophil count at $0 \mathrm{~min}, 30 \mathrm{~min}$ and $90 \mathrm{~min}$ after epidural administration of the drugs in all groups. Insulin fluctuated nonsignificantly around the baseline in all groups, except for a very significant decrease at $30 \mathrm{~min}$ in group $\mathrm{C}$, and a significant increase at the same interval in group B. Glucose values significantly increased in group D at 90 min. Cortisol showed a non-significant decrease from base values in all groups, except for a significant increase at $90 \mathrm{~min}$ in group A. The neutrophil count varied non-significantly at all intervals in all groups. No significant differences were recorded in glucose, cortisol and neutrophil count between the different groups at different intervals. It was concluded that dexmedetomidine, in combination with lidocaine, bupivacaine or ropivacaine, at the doses studied may be employed safely for epidural anaesthesia and analgesia, with adequate blunting of stress response during surgical procedures.

Key words: stress response; dexmedetomidine; local anaesthetics; bupivacaine; lidocaine and ropivacaine

\footnotetext{
*Corresponding author:

Dr. Mudasir Ahmad Shah, M.V.Sc Scholar, Division of Surgery, Indian Veterinary Research Institute, Izatnagar 243122, UP, India, Phone: +91 706035 6992; E-mail: syedmudasirshah907@gmail.com; drmudasirshah@ivri.res.in
} 
M. A. Shah et al.: Evaluation of stress response in atropine - midazolam premedicated dogs under epidural dexmedetomidine, with or without local anaesthetics

\section{Introduction}

Any surgical intervention induces a cascade of endocrine, metabolic and immunological changes, depending on the severity and duration of tissue injury (DESBOROUGH, 2000; SOOP et al., 2007). The rise in stress hormone levels during or after surgery aids haemodynamic instability, and intraoperative and postoperative catabolism (BOVILL et al., 1984) and leads to increased postoperative susceptibility to infections. An animal's stress response to surgery is mostly assessed by behavioural parameters, however, it would be more appropriate to include physiological indices, such as plasma cortisol concentrations (AGNATI et al., 1991). Different biochemical indices, such as serum cortisol, insulin, glucose and blood neutrophil count, have often been used as markers of pain and stress in veterinary medicine (ENQUIST et al., 1977; LIU et al., 1995; NICHOLSON et al., 1998; KEHLET, 2000).

Most sedative and analgesic drugs used in veterinary clinical practice are not effective stress reducers, thus paving the way for evaluating anaesthesiological protocols which adequately obtund the endocrine-metabolic or stress response to surgery (KEHLET, 1979). Previous studies have revealed neuraxial anaesthesia as a valuable option to prevent the endocrine and metabolic response to surgery (WOLF et al., 1993; LIU et al., 1995; MEISSNER et al., 1997; SIBANDA et al., 2006). Recent evidence suggests that local anaesthetics, used topically or as regional anaesthesia, block neural impulses from the surgical area and inhibit adrenocortical response to surgery (COSGROVE and JENKINS, 1974; KELBEL and WEISS, 2001; HOMBURGER and MEILER, 2006). Further, this effect of local anaesthetics can be augmented by adding different adjuvant drugs. Alpha2-adrenoceptor agonists have been effective in diminishing central sympathetic outflow and attenuating the stress response associated with surgery (AHO et al., 1992). Due to the centrally mediated anxiolytic action of midazolam, reduced adrenal response has been noted to electrical stress (PRADA et al., 1980).

The objective of this study was to assess the level of anaesthetic stress response as reflected by changes in insulin, glucose cortisol and neutrophil count, brought about by epidural dexmedetomidine and its combination with different local anaesthetics, in dogs subjected to elective ovariohysterectomy.

\section{Materials and methods}

Animals and study design. Prospective, randomized double-blinded clinical trials were performed in 24 healthy client-owned mixed breed adult dogs, with an average weight of $18.1 \pm 2.4 \mathrm{~kg}$, presented for elective ovariohysterectomy. The dogs were randomly $(\mathrm{n}=$

6) allotted to four groups, viz: A, B, C and D. The animals were kept off-fed for $12 \mathrm{~h}$ and written consent was obtained from the owner before attempting the surgery. 
M. A. Shah et al.: Evaluation of stress response in atropine - midazolam premedicated dogs under epidural dexmedetomidine, with or without local anaesthetics

Anaesthesia and surgical approach. All the animals were premedicated with atropine (Atropine sulphate injection $0.5 \mathrm{mg} / \mathrm{mL}$, Bhavani Pharmaceuticals (P) Ltd., India) 0.04 $\mathrm{mg} / \mathrm{kg}$ b.m., i/m and after 5 minutes midazolam (Mezolam $1 \mathrm{mg} / \mathrm{mL}$, Neon laboratories limited, India) $0.7 \mathrm{mg} / \mathrm{kg}$ b.m. i/v. Proper sedation was achieved after 10 minutes and then the animals were positioned in sternal recumbency, with the hind limbs flexed cranially, and the lumbosacral intervertebral space (L7-S1) was located. The area was shaved and aseptically prepared for epidural injection, and a $20 \mathrm{G}$ needle was correctly placed on the midline, caudal to the L7 spinous process and inserted until a distinct popping sensation was felt as the needle penetrated the interarcuate ligament. Epidural anaesthesia was administered by using dexmedetomidine (Dextomid $100 \mu \mathrm{g} / \mathrm{mL}$, Neon laboratories limited, India) at $7 \mu \mathrm{g} / \mathrm{kg}$ b.m. in group A, and in groups B, C and D, in addition to dexmedetomidine ( $7 \mu \mathrm{g} / \mathrm{kg}$ b.m.) lidocaine (LOX 2\%, Neon laboratories limited, India) $4.4 \mathrm{mg} / \mathrm{kg}$ b.m, bupivacaine (ANAWIN 0.5\%, Neon laboratories limited, India) $2 \mathrm{mg} /$ $\mathrm{kg}$ b.m and ropivacaine (ROPIN $0.75 \%$, Neon laboratories limited, India) $2 \mathrm{mg} / \mathrm{kg}$ b.m were administered, respectively. In all groups propofol (Nirfol 1\%, Nirlife limited, India) was used intravenously as an intraoperative supplemental anaesthetic agent as and when needed up until the end of the surgical procedure. Ovariohysterectomy was performed through the midline abdomen approach by the same group of surgeons in all the groups.

Blood sampling and biochemistry. Two $\mathrm{mL}$ of blood in disposable syringes containing heparin (1:1000) and $1 \mathrm{~mL}$ blood in clean dry vials, containing sodium fluoride, was collected from the cephalic vein of each animal at 0 minute (base line), 30 and 90 minutes after epidural administration of drugs. A fine blood smear was prepared from a drop of heparinised blood for estimation of differential leucocytic count to record neutrophil count $(\%)$ as described by SCHALM et al. (1975). The remaining heparinised blood was centrifuged at $3000 \mathrm{rpm}$ for $5 \mathrm{~min}$ and plasma was separated and stored at $-20{ }^{\circ} \mathrm{C}$ until assayed. This plasma sample was subjected to the estimation of plasma insulin ( $\mu \mathrm{IU} /$ $\mathrm{ml})$ and cortisol (nmol/L) by radioimmunoassay (RIA) procedure. The blood sample in sodium fluoride was centrifuged and plasma separated and stored at $-20{ }^{\circ} \mathrm{C}$ until used for estimation of plasma glucose (mmol/L) by GOD/POD method (TRINDER, 1969).

Statistical analysis. The data was checked for normality by applying the ShapiroWilk test. Analysis of Variance (ANOVA) and Duncan's multiple range test (DMRT) were used to compare the means at different time intervals among different groups. Oneway repeated measure analysis was used to compare the mean values at different intervals in each group (SNEDECOR and COCHRAN, 1994). The SPSS 20.0 (IBM., IL, USA) software was used to analyse the data. The differences were considered significant at $\mathrm{P}<0.05$ and very significant at $\mathrm{P}<0.01$ in each analysis. 
M. A. Shah et al.: Evaluation of stress response in atropine - midazolam premedicated dogs under epidural dexmedetomidine, with or without local anaesthetics

\section{Results}

All the groups revealed a slight $(\mathrm{P}>0.05)$ decrease in insulin level from their respective base values at all observation intervals, with the exception of a very significant $(\mathrm{P}<0.01)$ decrease in group $\mathrm{C}$ at $30 \mathrm{~min}$ with respect to the baseline. However, a significantly $(\mathrm{P}<0.05)$ higher insulin level was recorded in group B animals as compared to group $\mathrm{C}$ animals at the $30 \mathrm{~min}$ interval (Fig. 1).

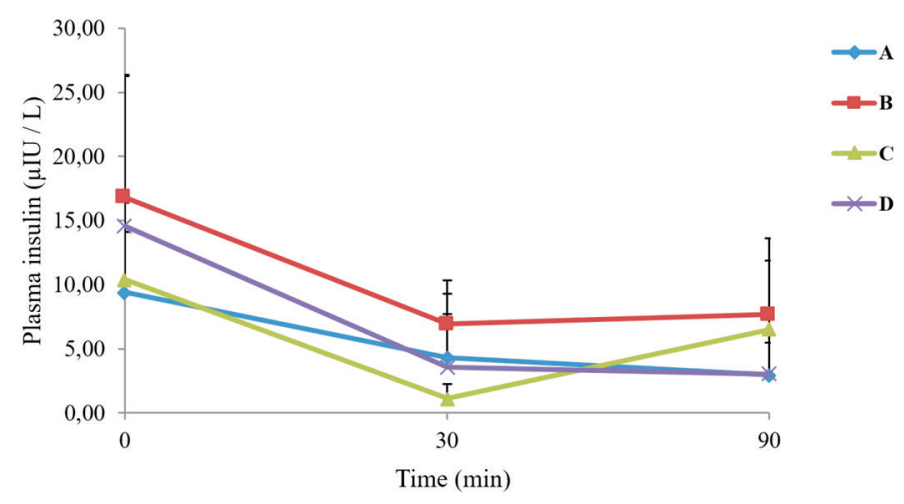

Fig. 1. Mean $\pm \mathrm{SD}$ values of plasma insulin $(\mu \mathrm{IU} / \mathrm{L})$ in different groups at different time intervals

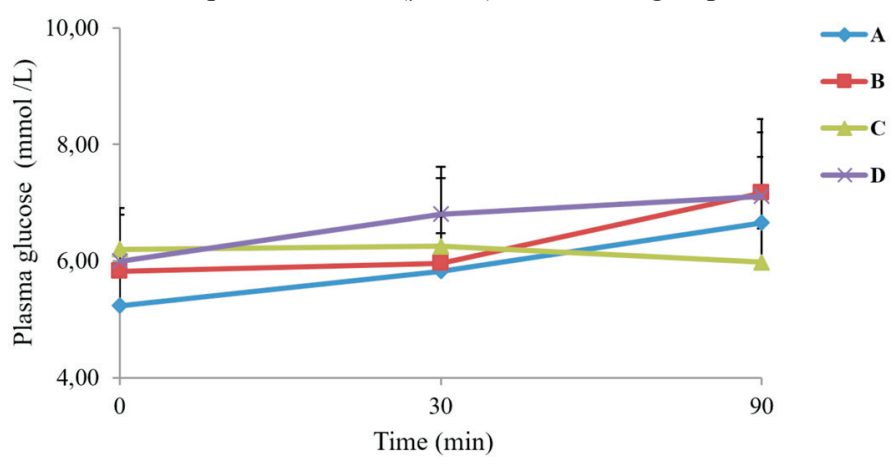

Fig. 2. Mean $\pm \mathrm{SD}$ values of plasma glucose $(\mathrm{mmol} / \mathrm{L})$ in different groups at different time intervals

Glucose values fluctuated and generally remained slightly $(\mathrm{P}>0.05)$ above baseline in all the groups, with the exception of a significant $(\mathrm{P}<0.05)$ increase in group $\mathrm{D}$ at $90 \mathrm{~min}$, and a non-significant $(\mathrm{P}>0.05)$ decrease at $90 \mathrm{~min}$ in group $\mathrm{C}$ (Fig. 2). 
M. A. Shah et al.: Evaluation of stress response in atropine - midazolam premedicated dogs under epidural dexmedetomidine, with or without local anaesthetics

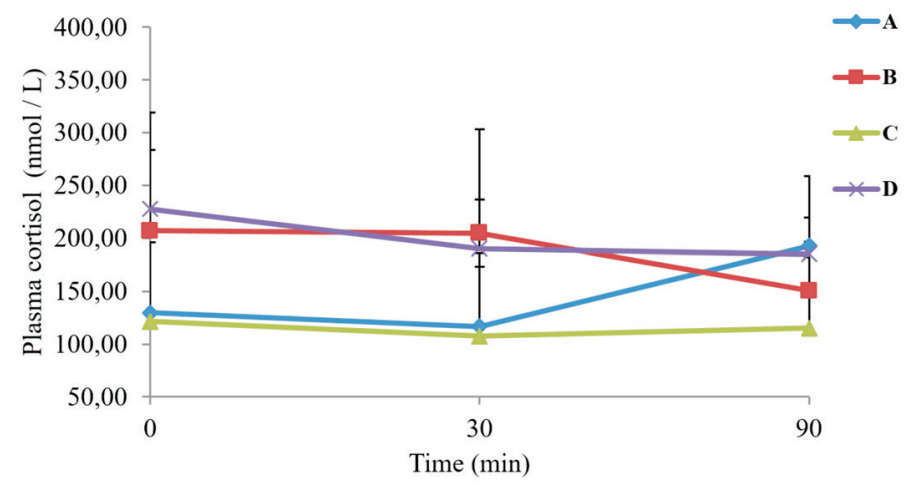

Fig. 3. Mean \pm SD values of plasma cortisol $(\mathrm{nmol} / \mathrm{L})$ in different groups at different time intervals

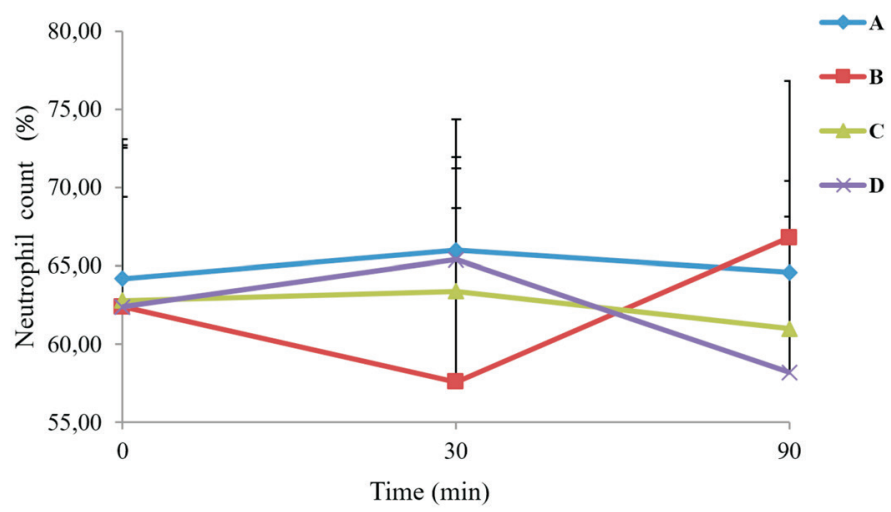

Fig. 4. Mean \pm SD values of neutrophil count (\%) in different groups at different time intervals

Cortisol levels decreased non-significantly $(\mathrm{P}>0.05)$ in all groups at all the observation intervals, except for a significant $(\mathrm{P}<0.05)$ increase at the 90 min interval in group A with respect to the baseline (Fig. 3). The neutrophil count fluctuated non-significantly $(\mathrm{P}>0.05)$ in all the groups from their respective baseline values. (Fig. 4)

No significant $(\mathrm{P}>0.05)$ differences were recorded in glucose, cortisol and neutrophil count among the different groups at the different intervals. It is important to mention here that group A animals consumed significantly $(\mathrm{P}<0.05)$ higher doses of intravenous propofol as compared to the other groups (Table 1). 
M. A. Shah et al.: Evaluation of stress response in atropine - midazolam premedicated dogs under epidural dexmedetomidine, with or without local anaesthetics

Table 1. Mean \pm SD values for doses of propofol used in different groups

\begin{tabular}{|l|c|}
\hline Groups & Dose of propofol $(\mathrm{mg} / \mathrm{kg})$ \\
\hline A & $6.89 \pm 3.60^{\mathrm{a}}$ \\
\hline B & $3.61 \pm 1.41^{\mathrm{b}}$ \\
\hline C & $2.77 \pm 0.67^{\mathrm{b}}$ \\
\hline D & $3.39 \pm 0.52^{\mathrm{b}}$ \\
\hline
\end{tabular}

Values with different superscript among groups differ significantly $(\mathrm{P}<0.05)$

\section{Discussion}

Local anaesthetic agents, when administered perineurally, epidurally or intrathecally, block the afferent neural impulses, thereby stopping them reaching higher centres in the central nervous system (CNS). It has been reported that alpha-2 adrenergic agonists inhibit $\beta$ cell insulin secretion during any surgical intervention (RAFEE et al., 2015). Earlier studies revealed significantly decreased serum insulin levels for several hours following medetomidine administration in dogs and cats (AMBRISKO and HIKASA, 2002; KANDA and HIKASA, 2008). However, alpha-2-adrenoceptor agonists effectively attenuate the stress response associated with surgery, by blocking central sympathetic outflow (AHO et al., 1992). The significantly higher insulin level in group B animals as compared to group $\mathrm{C}$ animals at the 30 min interval is suggestive of a relative difference in the lipophilicity of lidocaine and bupivacaine, thus causing an early inhibition of stress response in group B animals. HOLTE and KEHLET (2002) reported an unaltered plasma insulin concentration in patients receiving epidurally administered local anaesthetics for lower body procedures.

Hyperglycaemia has been suggested as a usual response to stress due to the rise in adrenocortical hormones (MIRAKHUR et al., 1984). These hormones stimulate gluconeogenesis and also reduce consumption of glucose by cells, and result in increased blood glucose concentration (GUYTON and HALL, 2006). HSU and HUMMAL (1981) reported the diminished transport of glucose through cell membranes and hyperactivity of the adrenal cortex as the factors responsible for blood glucose elevation following anaesthesia. Increase in blood glucose concentration has also been reported after medetomidine administration (BURTON et al., 1997), which can be related to inhibition of insulin secretion by pancreatic $\beta$ cells. Midazolam, when used alone, has been related to an insignificant increase in blood glucose levels (BUTOLA and SINGH, 2007), which is in line with our study. However the increase was statistically insignificant in all the groups with respect to their base values. VIJAYKUMAR et al. (2013) reported a significant reduction in serum glucose level during epidural injection, followed by a significant increase up to $6 \mathrm{~h}$ after surgery. The significant fall in plasma glucose in 
M. A. Shah et al.: Evaluation of stress response in atropine - midazolam premedicated dogs under epidural dexmedetomidine, with or without local anaesthetics

group $\mathrm{C}$ at the 90 min interval as compared to the baseline could be attributed to the effective inhibition of stress response by epidural bupivacaine and dexmedetomidine. It has been reported that dexmedetomidine, when added as an adjunct to bupivacaine, provides adequate anaesthesia and postoperative analgesia, and thus effective stress reduction (LI et al., 2014; SUN et al., 2015). However, FANI et al. (2008) showed a significant increase in blood glucose level after epidural administration of bupivacaine in dogs. The significant increase in plasma glucose level in group $\mathrm{D}$ at $90 \mathrm{~min}$ with respect to the baseline may be related to the diminishing effects of ropivacaine due to its weak sensory blockade potential, thus causing the least inhibition of neural impulses from the surgical site (BIGAT et al., 2006). KHODWE et al. (2013) reported a significant increase in plasma glucose after epidural administration of bupivacaine and ropivacaine in dogs. SINGH et al. (2005) recorded an increase in plasma glucose value after administration of ropivacaine in urolithic goats.

Cortisol has specifically been used as an indicator of physiological stress, and rises in cortisol concentrations have been corroborated with different surgical interventions (FRANK et al., 1992). LI et al. (2008) reported low levels of plasma cortisol during nephrectomy under epidural analgesia. NAKAMURA and. TAKASAKI (1991) reported no change in plasma cortisol levels when $1.5 \%$ mepivacaine was used as a caudal analgesia in children. Decreases in cortisol level in our study may be attributed to effective blockade of neural impulses, sedation and analgesia produced by the combination of epidural dexmedetomidine with local anaesthetics and high doses of preanaesthetic midazolam. Significantly higher serum cortisol levels have been reported for bupivacaine alone as compared to bupivacaine-morphine combination given interpleurally for median sternotomy in dogs (DHOKARIKAR et al., 1996). The significant increase in cortisol level at $90 \mathrm{~min}$ in group A may be related to maximum stress owing to the use of epidural dexmedetomidine alone. Further, group A animals consumed the maximum amount of intravenous propofol as compared to other groups for achieving deep sedation, thus hindering abdominal straining during the surgical procedure. This is suggestive of the least reduction of stress response in group A due to exaggerated excitatory descending modulation of spinal cord neurons, without sufficient suppression of motor function.

The insignificant change in neutrophil count in the different groups at various intervals can be related to adequate anaesthetic depth and blunting of surgical stress owing to the least variations in the duration of surgery in all the groups. SINGH et al. (2005) reported an increase in neutrophil count in a study on xylazine and lidocaine in buffalo calves. AMARPAL et al. (1998) reported a decrease in the neutrophil count in a study on alpha-2 agonists in dogs.

The statistically insignificant stress response, as reflected by insignificant changes in plasma insulin, glucose, cortisol and blood neutrophil count in this study, may be 
M. A. Shah et al.: Evaluation of stress response in atropine - midazolam premedicated dogs under epidural dexmedetomidine, with or without local anaesthetics

attributed to the blockade of afferent nociceptive neural traffic to reach the CNS, blockade of sympathetic efferent fibres that innervate the adrenal glands, adequate sedation and analgesia produced by epidural local anaesthetics with dexmedetomidine, along with heavy sedative doses of midazolam.

\section{Conclusion}

Dexmedetomidine in combination with lidocaine, bupivacaine and ropivacaine at the doses studied, revealed non-significant changes throughout the surgical procedure, barring a few intervals, thus paving the way for their safe use in epidural anaesthesia and analgesia with adequate blunting of stress response. However, the present study was part of an institutional post-graduaten programme and had to be completed within a period of 6 months, which restricted the number of clinical cases, thus obviating the possibility of any significant changes in the studied parameters between the different groups.

\section{Acknowledgements}

I am thankful to the Director and Joint Director (Academic \& Research), Indian Veterinary Research Institute, Izatnagar, India, for all the facilities provided by them during the period of my research work.

\section{References}

AGNATI, L. F., M. TIENGO, F. FERRAGUTI, G. BIAGINI, F. BENFENATI, C. BENEDETTI, M. RIGOLI, K. FUXE (1991): Pain analgesia and stress: an integrated view. Clin. J. Pain.7, 23-37.

DOI: $10.1097 / 00002508-199108000-00005$

AHO, M., M. SCHEININ, A. M. LEHTINEN, O. ERKOLA, J. VUORINEN, K. KORTTILA (1992): Intramuscularly administered dexmedetomidine attenuates hemodynamic and stress hormone responses to gynecologic laparoscopy. Anesth. Analg. 75, 932-939.

DOI: 10.1213/00000539-199212000-00011

AMARPAL, H., P.AITHAL, P. KINJAVDEKAR, K. PRATAP(1998): Physiological, haemodynamic and haematological changes due to medetomidine pethidine induced neurolept analgesia in experimental dogs. Indian J. Anim. Sci. 69, 106-108.

AMBRISKO, T. D., Y. HIKASA (2002): Neurohormonal and metabolic effects of medetomidine compared with xylazine in beagle dogs. Can. J. Vet. Res. 66, 42-49.

BIGAT, Z., N. BOZTUG, B. KARSLI, N. CETE, E. ERTOK (2006): Comparison of hyperbaric ropivacaine and hyperbaric bupivacaine in unilateral spinal anaesthesia. Clin. Drug Invest. 26, $35-41$.

DOI: $10.2165 / 00044011-200626010-00005$ 
M. A. Shah et al.: Evaluation of stress response in atropine - midazolam premedicated dogs under epidural dexmedetomidine, with or without local anaesthetics

BOVILL, J. G., P. S. SEBEL, T. H. STANLEY (1984): Opioid analgesia in anesthesia: with special reference to their use in cardiovascular anesthesia. Anesthesiology 61, 731-755.

DOI: 10.1097/00000542-198412000-00018

BURTON, S. A., K. A. LEMKE, S. L. IHLE, A. L. MACKENZIE (1997): Effects of medetomidine on serum insulin and plasma glucose concentrations in clinically normal dogs. Am. J. Vet. Res. $58,1440-1442$.

BUTOLA, A. V., B. SINGH, B (2007): Midazolam as tranquilizer in dogs. Indian Vet. J. 84, 1141 1145.

COSGROVDE, O., S. JENKINS (1974): The effects of epidural anaesthesia on the pituitary-adrenal response to surgery. Clin. Sci. Mol. Med. 46, 403-407.

DESBOROUGH, J. P. (2000): The stress response to trauma and surgery. Brit. J. Anaesth. 85, 109-117. DOI: $10.1093 / \mathrm{bja} / 85.1 .109$

DHOKARIKAR, P., D. D. CAYWOOD, D. STOBIE, M. R. RAFFE (1996): Effects of intramuscular or interpleural administration of morphine and interpleural administration of bupivacaine on pulmonary function in dogs that have undergone median sternotomy. Am. J. Vet. Res. 57, 375-380.

ENQUIST, A., M. R. BRANDT, A. FERNANDES, H. KEHLET (1977). The blocking effect of epidural analgesia on the adrenocortcial and hyperglycaemic responses to surgery. Acta Anaesth. Scand. 21, 330-35.

DOI: $10.1111 / \mathrm{j} .1399-6576.1977 . t b 01227 . x$

FANI, F., A. K. HALL, J. K. DOWLING (2008): Bupivacaine a clinical assessment in the lumbar extradural block. Vet. World. 1, 175-177.

FRANK, L. A., G. A. KUNKLE, K. M. BEALE (1992): Comparison of serum cortisol concentrations before and after intradermal testing in sedated and nonsedated dogs. J. Am. Vet. Med. Assoc. 200, 507-510.

GUYTON, A.C., J.E. HALL (2006): Textbook of Medical Physiology. $11^{\text {th }}$ ed., Saunders Elsevier Inc., Philadelphia, pp. 951-954.

HOLTE, K., H. KEHLET (2002): Epidural anaesthesia and analgesia-effects on surgical stress responses and implications for postoperative nutrition. Clin. Nutr. 21, 199-206.

DOI: $10.1054 /$ clnu.2001.0514

HOMBURGER, J. A., S. E. MEILER (2006): Anesthesia, drugs, immunity and long - term outcome. Curr. Opin. Anaesthesio. 19, 423-428.

DOI: 10.1097/01.aco.0000236143.61593.14

HSU, W. H., S. K. HUMMAL (1981): Xylazine induced heperglycemia in cattle: possible involvement of $\alpha 2$ adrenergic receptors regulating insulin release. Endocrinol. 109, 825.

DOI: 10.1210/endo-109-3-825

KANDA, T., Y. HIKASA (2008): Effects of medetomidine and midazolam alone or in combination on the metabolic and neurohormonal responses in healthy cats. Can. Vet. J. 72, 332-339.

Vet. arhiv 88 (6), 823-834, 2018 
M. A. Shah et al.: Evaluation of stress response in atropine - midazolam premedicated dogs under epidural dexmedetomidine, with or without local anaesthetics

KEHLET, H. (1979): Stress-free anaesthesia and surgery. Acta Anaesth. Scand. 23, 503.

KEHLET H (2000). Manipulation of the metabolic response in clinical practice. World J. Surg. 24, 690-695.

DOI: $10.1007 / \mathrm{s} 002689910111$

KELBEL, I., M. WEISS (2001): Anaesthetics and immune function. Curr. Opin. Anaesthesio. 14, 685-691.

DOI: $10.1097 / 00001503-200112000-00015$

KHODWE, S., B. P. SHUKLA, R. AHMAD (2013): Studies on clinicophysiological and haematobiochemical evaluation of bupivacine, ropivacaine and ropivacaine-xylazine combination as an epidural analgesic in dogs. Int. J. Adv. Res. 1, 31-35.

LI, Y., S. ZHU, M. YAN (2008): Combined general/epidural anesthesia (ropivacaine 0.375\%) versus general anesthesia for upper abdominal surgery. Anesth. Analg. 106, 1562-1565.

DOI: 10.1213/ane.0b013e31816d1976

LI, Z., M. TIAN, C. Y. ZHANG, A. Z. LI, A. J. HUANG, C. X. SHI, D. Q. XIN, J. QI, K. Z. LI (2014): A randomized controlled trial to evaluate the effectiveness of intrathecal bupivacaine combined with different adjuvants (fentanyl, clonidine and dexmedetomidine) in caesarean section. Drug Res. 65, 581-586.

DOI: $10.1055 / \mathrm{s}-0034-1395614$

LIU, S., R. L. CARPENTER, J. M. NEAL (1995): Epidural anesthesia and analgesia: their role in postoperative outcome. Anesthesiology 82, 1474-1506.

DOI: 10.1097/00000542-199506000-00019

MEISSNER, A., N. ROLF, H. VAN AKEN (1997): Thoracic epidural anesthesia and the patient with heart disease: benefits, risks, and controversies. Anesth. Analg. 85, 517-528.

DOI: 10.1213/00000539-199709000-00008

MIRAKHUR, K. K., V. K. SOBTI, J. M. NIGAM (1984): Effect of thiopentone anaesthesia on plasma catecholamine and cortisol in buffalo calves (Bubalus bubalis). Indian J. Vet. Surg. 3, 86-88.

NAKAMURA, T., M. TAKASAKI (1991): Metabolic and endocrine responses to surgery during caudal analgesia in children. Can. J. Anaesth. 38, 969-973.

DOI: 10.1007/BF03008613

NICHOLSON, G., G. M. HALL, J. M. BURRIN (1998). Peri-operative steroid supplementation. Anaesthesia 53, 1091-1094.

DOI: $10.1046 / \mathrm{j} .1365-2044.1998 .00578 . \mathrm{x}$

PRADA, M. D. A, L. PIERI, G. B. PICOTII (1980): Effects of midazolam (a water soluble benzodiazepine) on stress-induced increase of plasma catecholamines. In: Catecholamines and Stress: Recent Advances. (Usdin, E., R. Kvetriansky, I. J. Kopin, Eds.), Elsevier, North Holland, pp. 2314. 
M. A. Shah et al.: Evaluation of stress response in atropine - midazolam premedicated dogs under epidural dexmedetomidine, with or without local anaesthetics

RAFEE, M. A., P. KINJAVDEKAR, AMARPAL, H. P. AITHAL, S. A. WANI P. SAMGEETHA (2015): Haematobiochemical changes and postoperative complications following elective ovariohysterectomy in dogs. Global J. Inc. 15, 1-5.

SCHALM O. W., N. C. JAIN, J. CARROLI E (1975): Veterinary Haematology. $3^{\text {rd }}$ ed., Philadelphia, Pennsylvania, pp. 245.

SIBANDA, S., J. M. L. HUGHES, P. E. PAWSON, G. KELLY, C. R. BELLENGER (2006): The effects of preoperative extradural bupivacaine and morphine on the stress response in dogs undergoing femoro-tibial joint surgery. Vet. Anaesth. Analg. 33, 246-257.

DOI: 10.1111/j.1467-2995.2005.00261.X

SINGH, K., P. KINJAVDEKAR, AMARPAL, H. P. AITHAL, A. GOPINATHAN, G. R. SINGH, T. SINGH, A. M. PAWDE, K. PRATAP (2005): Clinico-physiological and haematobiochemical effects of epidural ropivacaine in uraemic and healthy caprines. Indian J.Vet. Surg. 26, 11-15.

SNEDECOR, G. W., W. G. COCHRAN (1994): Statistical Methods, $9^{\text {th }}$ ed., Iowa State University Press.

SOOP, M., J. NYGREN, A. THORELL, O. LJUNGQVIST (2007): Stress-induced insulin resistance: recent developments. Curr. Opin. Clin. Nutr. Metab. Care. 10, 181-186.

DOI: 10.1097/MCO.0b013e32801481df

SUN, Y., Y. XU, G. N. WANG (2015): Comparative evaluation of intrathecal bupivacaine alone, bubivacaine-fentanyl, and bupivacaine-dexmedetomidine in cesarean section. Drug Res. 65, 468-472.

TRINDER, P. (1969): Use of glucose oxidase, perioxidase and o. dianiside in determination of blood and urinary glucose. Ann. Clin. Biochem. 6, 264-273.

DOI: $10.1177 / 000456326900600108$

VIJAYAKUMAR, M., S. DHARMACEELAN, P. SELVARAJ, N. RAJENDRAN (2013): Physiological, haemodynamic and biochemical changes during epidural bupivacaine alone or with buprenorphine for ovariohysterectomy in dogs. Indian J. Vet. Surg. 34, 91-93.

WOLF, A. R., R. L. EYRES, P. C. LAUSSEN, J. EDWARDS, I. J. STANLEY, P. ROWE, L. SIMON (1993): Effect of extradural analgesia on stress responses to abdominal surgery in infants. Brit. J. Anaesth. 70, 654-660.

DOI: $10.1093 / \mathrm{bja} / 70.6 .654$

Received: 31 October 2017

Accepted: 22 October 2018

Vet. arhiv 88 (6), 823-834, 2018 
M. A. Shah et al.: Evaluation of stress response in atropine - midazolam premedicated dogs under epidural dexmedetomidine, with or without local anaesthetics

SHAH, M. A., P. KINJAVDEKAR, AMARPAL, D. SHARMA, R. KUMAR, N.
KALLIANPUR, S. SHIVARAMU, P. KAMARAJ: Odgovor na stres u pasa pod
epiduralnom anestezijom deksmedetomidinom uz primjenu lokalnih anestetika ili
bez njih i premedikaciju atropin-midazolamom. Vet. arhiv 88, 823-834, 2018.
SAŽETAK

Cilj istraživanja bio je procijeniti odgovor na stres u pasa pod epiduralnom anestezijom deksmedetomidinom, uz primjenu lokalnih anestetika ili bez njih, kojima je kao premedikacija dan atropin-midazolam. Uključena su 24 zdrava odrasla psa mješanca, u vlasništvu klijenata. Prosječna tjelesna masa pasa iznosila je $18,1 \pm$ $2,4 \mathrm{~kg}$. Metodom slučajnog izbora psi su podijeljeni u četiri skupine iste veličine $(\mathrm{n}=6) \mathrm{s}$ oznakama $\mathrm{A}, \mathrm{B}$, C i D. Sve su životinje za premedikaciju intramuskularno dobile atropin $(0,04 \mathrm{mg} / \mathrm{kg})$ i nakon pet minuta intravenski midazolam $(0,7 \mathrm{mg} / \mathrm{kg})$. Deset minuta poslije premedikacije svim je skupinama u lumbosakralni epiduralni prostor dan deksmedetomidin $(7 \mu \mathrm{g} / \mathrm{kg}), \mathrm{s}$ tim da je skupini B dodan i lidokain $(4,4 \mathrm{mg} / \mathrm{kg}), \mathrm{skupini}$ $\mathrm{C}$ bupivakain $(2 \mathrm{mg} / \mathrm{kg})$, a skupini D ropivakain $(2 \mathrm{mg} / \mathrm{kg})$. Anestezija je održavana $1 \%$-tnim propofolom prema potrebi. Odgovor na stres za vrijeme kirurškog zahvata ustanovljen je mjerenjem razina inzulina, glukoze, kortizola u plazmi i broja neutrofila u krvi. Navedeni pokazatelji mjereni su 0 minuta, 30 minuta i 90 minuta nakon epiduralne primjene lijekova u svim skupinama. Vrijednosti inzulina nisu pokazale veću promjenjivost, osim statistički visoko značajnog smanjenja u skupini C nakon 30 minuta i statistički značajnog povećanja u skupini B u istom intervalu. Kod pasa iz skupine D razina glukoze značajno je porasla u 90. minuti. Smanjenje razina kortizola u svim skupinama nije bilo značajno, a u skupini A opažen je značajni porast ovog pokazatelja 90 minuta nakon primjene lijekova. Broj neutrofila nije značajnije varirao ni u jednoj skupini i ni u jednom intervalu mjerenja. Nije bilo značajnih razlika u razinama glukoze i kortizola te broju neutrofila među skupinama u različiitm intervalima. Zaključeno je da se sa svrhom smanjenja stresa pri kirurškim zahvatima za epiduralnu anesteziju i analgeziju sigurno može rabiti deksmedetomidin u kombinaciji s istraženim dozama lidokaina, bupivakaina ili ropivakaina.

Ključne riječi: odgovor na stres; deksmedetomidin; lokalni anestetici; bupivakain; lidokain; ropivakain 